\title{
Employee Welfare Schemes and Its Implication in Performance in Lear Automotive Private Limited, Chennai
}

\author{
S.Divyabharathi ${ }^{1}$ RP.Nivethigha ${ }^{2}$ \\ ${ }^{I}$ Research Scholar, Anna University, Chennai \\ ${ }^{2}$ Research Scholar, Anna University, Chennai
}

\begin{abstract}
Defined Employee welfare as a term which is understood to include such services, facilities and amenities as may be established in or in the vicinity of undertakings to enable the persons employed in them to perform their work in healthy, congenial surrounding and to provide them with amenities conductive to good health and high morale. Worker's Health Services -Factory health center; dispensary, ambulance, emergency aid, medical examination for workers; health education, health research; family planning services. Women and Child Welfare-Antenatal and postnatal care, maternity aid, crèche and child care; women's general education; separate services for women wormers, tat is lunch rooms, urinals rest rooms, women's recreation (indoor); family planning services. Worker's Recreation-Indoor games; strenuous games to be avoided during intervals of work. Employment Follow up-Progress of the operative in his/her work; his /her adjustment problems with regard to machines and workload, supervisors and colleagues; industrial counseling. Economic Services- Cooperatives, loans, financial grants; thrift and saving schemes; budget knowledge, unemployment insurance, health insurance, employment bureau, profit-sharing and bonus schemes; transport family assistance in time of need. Labour-Management Participation-Formation and working of various committees, that is works committee, safety committee, canteen committee; consultation in welfare area, in the area of administration, in the area of public relations. This study focuses on the improvement of the welfare schemes provided to all the employees and to improve their working environment.
\end{abstract}

Keywords: Worker's Health Services, Women and Child Welfare, Worker's Recreation, Economic Services, Management Participation

\section{Need of The Study}

Of the $5 \mathrm{~m}$ 's management man, machine, material, methods, and money, out of these resources manpower is an asset to the organization. It also called knowledge capital or knowledge resources. As the management Guru Peter F. Drucker rightly says "knowledge is the only meaningful resource today" for access to other resources is no longer, limited. Capital flows freely across borders, seeking out the companies that need it. Technology is available to the CEO's who cannot grow it- for the right price raw material is free to be transported across the globe. Information is also available to everyone. Today the human resources is very demanding and they look at jobs to test their own knowledge, organization are also realizing the importance of people resources in this liberalized, Globalize \& privatized economy. In order to make them happy, feel satisfied and retain them, organization plan retention strategies. To make this possible one has to determine what the present employee's perceived satisfaction used towards the employee welfare. The survey on employee satisfaction win helps the organization to evaluate its return on investment in the important area like employee welfare measures.

\section{Statement of the Problem}

The liberalization, privatization and globalization of Indian economy in the last few years have presented unprecedented challenges to the decision makers in government, industry and service sectors; to compete in the global market with competitive edge necessitates the industry Defined Employee welfare as a term which is understood to include such services, facilities and amenities as may be established in or in the vicinity of undertakings to enable the persons employed in them to perform their work in healthy, congenial surrounding and to provide them with amenities conductive to good health and high morale.

\footnotetext{
Objective of the Study

Primary Objective

$>$ To study the employee welfare on Lear automotive India Pvt Ltd.

Secondary Objective

$>$ To study the existing welfare measures adopted by the organization.

$>$ To identify the impact of the welfare measures upon the workers health and productivity.

$>$ To give some suggestions to increase the job satisfaction and productivity of the employees.

$>$ To maintain good relationship in between the employer and employees
} 


\section{Scope of The Study}

The usefulness of welfare facilities in India cannot be over emphasized. Welfare activities influence the sentiments of the workers. When the workers feel that the employers and the state are interested in their happiness, his tendency to grouse and grumble will steadily disappear. The development of such a feeling, paves the way for industrial peace. Welfare measures such as cheap food in canteen, free medical and education facilities etc. indirectly the real income of the workers. If workers go on strike they will be deprived of all these facilities. Hence, they try to avoid industrial dispute as far as possible and do not go on strike on flimsy grounds.

Welfare activities will reduce employee turnover and absenteeism and create permanent settled employee force by making service attraction to the employee. Welfare activities will go on long way to better the mental and moral health of the workers by reducing the incidence of industrialization. Employee welfare measures develop congenial environment, and builds a good atmosphere between the employee and the management. Employee welfare creates positive work culture, builds team work to meet the challenges of the organization and increase efficiency for the workers whereby the productivity will increase. Skilled workers are the assets of an organization. Lab our welfare helps to retain the skilled workers and builds loyalty and sense of belongingness among them. Employees attitudes and appreciation towards the organization, will progress the unit. Good relation can be achieved through Employee welfare. This will strengthen the organization manifold. Above all employee welfare helps the organization from heavy tax-burden, and to meet legal requirements.

\section{Methodology}

The descriptive research design was used. This study used to collect the both primary and secondary data. The primary data were collected form employees in Lear Automotive Ltd., Chennai. Totally 100 respondents were chosen based on the convenience sampling method. All the respondents were answer the structured questionnaire. The collected data were analysis with percentage analysis. Chi-square, and Weighted average method. The SPSS 16 was used to analyze the collected data.

\section{Limitations of the Study}

$>$ The time period of the study is very short, so elaborate study was not made.

$>$ Only certain factors are considered in this study to measure the effect of welfare measure

$>$ The respondent had the fear that the questionnaire may be shown to the management.

$>$ The data obtained is qualitative but not quantitative and it is subjected to human error.

\section{Literature Review}

Shantamani .C (1999) ${ }^{1}$ conducted "A Study on the Attitude of Workers towards Labor Welfare Facilities" undertaken by lakshmi mills company ltd., Coimbatore. The objectives of this study were to have an idea about the extent utilization of the existing labor welfare facilities by the owned the attitude of the workers towards various welfare facilities. The tools used for collection of primary data were questionnaire. The no of respondents was 80 . The data was analyzed using percentage method. It was found that the majority of the employees were satisfied with heat, dust and noise control provisions provided by their company and canteen was regularly used only by 68 percent of the workers. It was suggested to adopt better housing facilities and to the improvement and betterment for the members of the voluntary arrangements.

Thamna Mohan, (2002) $)^{2}$, made an attempt to study "Labour Welfare Provided by Apollo Tyres Limited, Kalamassery". The researcher has taken 125 employees as the sample size. The size of the universe is 1230 employees and the researcher has used random sampling method. Probability sampling is also known as 'random sampling' under this sampling design, every item of the universe has an equal chance of inclusion in the sample. The objectives of the study were to study the effectiveness of labour welfare provided by the company, to study the various voluntary and statutory welfare measure provided by the company and to study workers participation in welfare activities. It was suggested and concluded that adequate funds were not provided for medical facility by the company. It is suggested that the company may think of increasing their as well as the employees contribution to the medical fund.

Jyothi.V (2003) $)^{3}$ conducted "A Study on Labor Welfare Facilities in Mysore Kirloskar Limited", Branch Factory, Hubli. The primary data was collected using random sampling technique by means of questionnaires and interview. The sample size was 84 workers. The data was analyzed using percentage method. From the findings, it was found that the management had not provided many welfare facilities like housing facilities and transportation facilities. It was found that the employees were satisfied with the canteen facilities, drinking water, sanitary and safety provisions. It was suggested on the basis of the findings that the management should give a good deal of attention to the housing and transportation facilities.

Bindya Sukumar, (2004) ${ }^{4}$, conducted a study "Labour Welfare Measures Adopted by Apollo Tyres Limited at Perambra". The company has total employee strength of 800. The workers work in three shifts i.e. Around 260 workers in each shift. As it is difficult to meet every employees. The researcher adopted a Simple 
random sampling technique to select a sample size of 81 employees covering three shifts. The Objectives were to study about the statutory and non-statutory welfare measures implemented in Apollo Tyres Ltd., to observe the levels of satisfaction of the workers with regard to the statutory and non-statutory welfare measures provided by Apollo Tyres Ltd., and to give suggestions to improve the levels of satisfaction with regard to the welfare measures of Apollo Tyres Ltd.

\section{Research Design}

A plan of proposed study prepared by a researcher stating the research activities to be performed in his proposed study before he undertakes his research work is called "Research Design" 100 respondents were selected for the survey in the various departments. Convenient sampling method is used to collect the data for structured questionnaire.

\section{Data Collection}

\section{Primary data}

The present study is based on the primary data collected from the employees of Lear automotive Pvt Ltd.

\section{Secondary data}

This data taken from the company profile website, journals and books for use of research study

Questionnaire were constructed based on the closed end type question..

\section{Weighted Average Method}

The weighted average method can be calculated by the following formula. This tool is used to find the rank given by the respondents to the welfare measures. It can be calculated as

Here

$$
\mathrm{XW}=\sum \mathrm{WX} / \sum \mathrm{X}
$$

XW represents the weighted average

$\mathrm{X}$ represents the value of variable

$\mathrm{W}$ represents the weight given to the variable.

Weighted average is analyzed on relationship with canteen, transport, safety measures and environment

Table: Relationship with Canteen

\begin{tabular}{|c|c|c|c|c|c|c|c|c|c|}
\hline \multicolumn{10}{|c|}{ Canteen } \\
\hline $\begin{array}{l}\text { S. } \\
\text { No }\end{array}$ & Particulars & $\begin{array}{l}\text { SA } \\
\text { (5) }\end{array}$ & $\begin{array}{l}A \\
\text { (4) }\end{array}$ & $\begin{array}{l}\text { UD } \\
\text { (3) }\end{array}$ & $\begin{array}{l}\mathbf{D A} \\
(2)\end{array}$ & $\begin{array}{l}\text { SDA } \\
\text { (1) }\end{array}$ & $\begin{array}{l}\text { Weighted } \\
\text { Value }\end{array}$ & $\begin{array}{l}\text { Weighted } \\
\text { Average }\end{array}$ & Rank \\
\hline 1. & $\begin{array}{l}\text { Food given with } \\
\text { good quality }\end{array}$ & 50 & 20 & 10 & 12 & 8 & 432 & 21.6 & I \\
\hline 2. & $\begin{array}{l}\text { Food served at } \\
\text { right time }\end{array}$ & 16 & 36 & 32 & 8 & 8 & 344 & 17.2 & III \\
\hline 3. & $\begin{array}{l}\text { canteen place } \\
\text { looks hygiene }\end{array}$ & 220 & 96 & 48 & 20 & 6 & 390 & 19.5 & II \\
\hline
\end{tabular}

It is inferred from the table that food given with good quality got rank first followed by canteen place looks hygiene ranked second and food served at right time is ranked last.

Table: Relationship with Transport

\begin{tabular}{|c|c|c|c|c|c|c|c|c|c|}
\hline \multicolumn{10}{|c|}{ Transport } \\
\hline S. No & Particulars & $\begin{array}{l}\text { SA } \\
\text { (5) }\end{array}$ & $\begin{array}{l}\text { A } \\
\text { (4) }\end{array}$ & $\begin{array}{l}\text { UD } \\
(3)\end{array}$ & $\begin{array}{l}\text { DA } \\
\text { (2) }\end{array}$ & $\begin{array}{l}\text { SDA } \\
\text { (1) }\end{array}$ & $\begin{array}{l}\text { Weighted } \\
\text { Value }\end{array}$ & $\begin{array}{l}\text { Weighted } \\
\text { Average }\end{array}$ & Rank \\
\hline 1. & $\begin{array}{l}\text { Availability of } \\
\text { transport on required } \\
\text { place }\end{array}$ & 68 & 30 & 2 & - & - & 466 & 23.3 & I \\
\hline 2. & $\begin{array}{l}\text { transport is provided } \\
\text { on emergency case }\end{array}$ & 26 & 48 & 24 & - & 2 & 344 & 19.8 & III \\
\hline 3. & $\begin{array}{l}\text { Driving skills of the } \\
\text { driver and route } \\
\text { knowledge }\end{array}$ & 50 & 26 & 16 & - & 8 & 410 & 20.5 & II \\
\hline
\end{tabular}

It is indicated from above table that availability of transport on required place is got rank first followed Driving skills of the driver and route knowledge is got ranked second and Transport is provided on emergency case is get last rank. 
Table: Relationship With Safety Measures

\begin{tabular}{|l|l|l|l|l|l|l|l|l|l|}
\hline \multicolumn{9}{|c|}{ Safety Measures } \\
\hline S. No & Particulars & $\begin{array}{l}\text { HS } \\
(\mathbf{5})\end{array}$ & $\begin{array}{l}\text { S } \\
(\mathbf{4})\end{array}$ & $\begin{array}{l}\text { UD } \\
(\mathbf{3})\end{array}$ & $\begin{array}{l}\text { DS } \\
(\mathbf{2})\end{array}$ & $\begin{array}{l}\text { HDS } \\
(\mathbf{1})\end{array}$ & $\begin{array}{l}\text { Weighted } \\
\text { Value }\end{array}$ & $\begin{array}{l}\text { Weighted } \\
\text { Average }\end{array}$ & Rank \\
\hline $\mathbf{1 .}$ & $\begin{array}{l}\text { Fire extinguisher placed } \\
\text { at convenient place }\end{array}$ & 66 & 20 & 14 & - & - & 452 & 22.6 & I \\
\hline $\mathbf{2 .}$ & $\begin{array}{l}\text { safety shoe and proper } \\
\text { dress code help in } \\
\text { prevent from accident. }\end{array}$ & 24 & 14 & 40 & 18 & 4 & 336 & 16.8 & II \\
\hline $\mathbf{3 .}$ & $\begin{array}{l}\text { Safety awareness drills } \\
\text { are conducted at proper } \\
\text { intervals }\end{array}$ & 22 & 22 & 20 & 20 & 16 & 314 & 15.7 & III \\
\hline
\end{tabular}

It is understood from above table that Fire extinguisher placed at convenient place is got rank first followed by safety shoe and proper dress code help in prevent from accident got rank second and ranked last on safety awareness drills are conducted at proper intervals.

Table: Relationship with Environment

\begin{tabular}{|c|c|c|c|c|c|c|c|c|c|}
\hline \multicolumn{10}{|c|}{ Environment } \\
\hline S. No & Particulars & $\begin{array}{l}\text { HS } \\
(5)\end{array}$ & $\begin{array}{l}S \\
(4)\end{array}$ & $\begin{array}{l}\text { UD } \\
\text { (3) }\end{array}$ & $\begin{array}{l}\text { DS } \\
(2)\end{array}$ & $\begin{array}{l}\text { HDS } \\
\text { (1) }\end{array}$ & $\begin{array}{l}\text { Weighted } \\
\text { Value }\end{array}$ & $\begin{array}{l}\text { Weighted } \\
\text { Average }\end{array}$ & Rank \\
\hline 1. & $\begin{array}{l}\text { Work environment have } \\
\text { moderate temperature }\end{array}$ & 62 & 22 & 14 & - & 2 & 442 & 22.1 & I \\
\hline 2. & $\begin{array}{l}\text { Have enough place between } \\
\text { employee in work place }\end{array}$ & 18 & 28 & 28 & 14 & 12 & 326 & 13.26 & III \\
\hline 3. & $\begin{array}{l}\text { Company contribute to Eco } \\
\text { friendly environment. }\end{array}$ & 58 & 10 & 14 & 12 & 6 & 402 & 20.1 & II \\
\hline
\end{tabular}

It is stated form above table that work environment have moderate temperature is ranked first followed Company contribute to Eco friendly environment got rank second and Have enough place between employee in work place is ranked last.

\section{Conclusion}

From the critical study organization is highly satisfied on quality and hygiene of food, Transport on required place, Satisfied on drinking water, organization provide eco friendly environment and employee satisfied on moderate temperature in working conditions. Employee unsatisfied on the food served at right time, taste and hygiene of drinking waste, dress code and safety shoe provided in the organization for safety purpose, Space between the employees in work place. The organization may concentrate on social security's like workmen compensation, maternity benefit, old age benefit, medical benefit etc which helps to increases employee job satisfaction.

\section{Textbooks}

\section{References}

[1]. Aswathappa.k, Human Resource and Personnel Management, Tata Mc Graw Hill, 1999, New Delhi.

[2]. Bernardin H. Human Resource Management, on Experimental Approach, Tata Mc Graw Hill, 2002, New Delhi.

[3]. Gary.D, Human Resource Management, Prentice Hall, Tenth Edition 2004, New Delhi.

[4]. Gupta, S.P., and Gupta, M.P., Business Statistics, Published by Sultan Chand \& Sons, $7^{\text {th }}$ Edition, 1989.

[5]. Kothari C.R., Research methodology, published by Tata Mc Graw-Hill Publishing Company Ltd., $13^{\text {th }}$ Edition, 1982. Website

[6]. www.visualsoftindia.com/journal.html

[7]. www.vrsdjournals.com

[8]. www.acedemicjournal.com

[9]. www.mairec.org

[10]. www.skirec.com 